\title{
Development of electrically conductive concrete
}

\section{(Desenvolvimento de concreto condutor de eletricidade)}

\author{
H. C. F. Cordon ${ }^{1 *}$, F. B. Tadini ${ }^{1}$, G. A. Akiyama ${ }^{1}$, V. O. de Andrade ${ }^{1}$, R. C. da Silva \\ ${ }^{1}$ Instituto Mauá de Tecnologia, Pç. Mauá 01, 09580-900, S. Caetano do Sul, SP, Brazil
}

\begin{abstract}
The effects of the addition of steel fiber and graphite powder on the electric conductivity of concrete were investigated. The percolation transition zone of the concrete + steel fiber was determined, thus fixing the optimum content of steel fiber at $8.5 \%$. Graphite was added to investigate its influence on the electrical conductivity and mechanical properties of the concrete. The electric current passing through the specimens was measured, setting the electric voltage to $50 \mathrm{~V}$. The surface temperature of the specimens submitted to the electrical current was measured for $20 \mathrm{~min}$. It was observed that the higher the graphite addition, the higher the conductivity was and, therefore, the higher the final temperature, which achieved $58{ }^{\circ} \mathrm{C}$ higher than the reference mixture, but the compressive strength decreased from 60 to $30 \mathrm{MPa}$, although still considered as structural concrete.
\end{abstract}

Keywords: electrical conductivity, concrete resistivity, graphite powder, steel fiber.

Resumo

Os efeitos da adição de fibra de aço e pó de grafita na condutividade elétrica do concreto foram investigados. Determinou-se o limiar de percolação do concreto + fibra de aço, fixando-se o teor ótimo de fibras em $8.5 \%$. O pó de grafita foi adicionado para investigar sua influência na condutividade elétrica e nas propriedades mecânicas do concreto. Mediu-se a corrente elétrica passante pelos corpos de prova, aplicando-se uma tensão de $50 \mathrm{~V}$. A temperatura superficial dos corpos de prova submetidos à passagem de corrente elétrica foi medida durante $20 \mathrm{~min}$. Observou-se que quanto maior a adição de grafita, maior foi a condutividade e, portanto, maior a temperatura final, que atingiu $58^{\circ} \mathrm{C}$ a mais que a mistura de referência, mas a resistência à compressão reduziu de 60 para $30 \mathrm{MPa}$, porém ainda sendo considerado um concreto para fins estruturais.

Palavras-chave: condutividade elétrica, resistividade do concreto, pó de grafita, fibra de aço.

\section{INTRODUCTION}

By combining the structural capacity of the concrete together with properties of materials like steel fiber and graphite, which are excellent thermal and electrical conductors, the concrete itself gains the capacity of allowing an electric current passing through it, what does not happen with the conventional concrete, which is practically electric insulating. The passage of the electric current through the concrete promotes a rise in the composite temperature [1]. The conductive concrete can be used for room heating and pavement deicing, for example. In cold regions, it could replace the mobilization of labor and heavy machinery for snow removal and could also replace the application of salt and other chemicals on roads that cause damaging action on reinforced concrete structures [2]. Adding conductive filler to the cementitious matrix may increase the electrical conductivity of the composite [3]. The desired conductivity is more efficiently achieved when a specific content of fibers is added to the composite with a conductive material. For each aggregate ratio there is an optimum content of filler,

*heloisa.fernandes@maua.br

Dhttps://orcid.org/0000-0002-8086-1331 above which there is a contact between fibers (conductive stage) and below which the percolation transition zone (or percolation threshold - volume fraction above which the fibers touch each other to form a continuous electrical path) is not reached and then the mixture is not conductive (insulating stage) [3-5]. When the steel fiber concentration achieves the percolation transition zone, the electrical conductivity of the mixture increases due to the formation of conductive paths that favors the transport of electrons in the system [4]. The addition of more conductive material, above the percolation transition zone, is no longer significant for the increase in conductivity and only make the workability worse (excess of fiber phase) [6].

The combination of steel or carbon fibers and graphite powder allows better control of the resistivity range than the use of each of them separately. The metal fiber is more effective than graphite for improving the conductivity of the material. Thus, a large amount of steel fiber can make concrete conductive, but conductivity cannot be manipulated by the use of fibers. Electrical resistivity must gradually decrease with increasing conductive material content. This is only possible with a combination of fibers and fillers, as the graphite powder ensures short-range contact with the fibers, reaching a kind of conductive bridge [7]. El-Dieb et al. [8] found that the highest improvement in electrical 
conductivity of the concrete mixtures was achieved with the use of graphite powder when compared to other fillers like steel shavings and carbon powder, but its use negatively impacts compressive strength. This is because it crystallizes in a hexagonal system, forming layers of atoms in the same plane. These layers of atoms are loosely bound to each other, which makes graphite a good lubricant. For this reason, the amount of graphite used in the concrete must be carefully dosed so that it does not compromise as much as possible its mechanical performance [9].

A successful application of a conductive concrete was carried out by Tuan [1] to the Roca Bridge in Nebraska (USA). The ideal blend found, with good workability and electrical conductivity, contained $1.5 \%$ of steel fibers and $25 \%$ of combined carbon and graphite products per volume unit. The compressive strength of the concrete mixture varied from 41 to $55 \mathrm{MPa}$. The bridge slab temperature raised $9{ }^{\circ} \mathrm{C}$ above the ambient temperature. After the construction and use of the bridge, economic viability was proven in relation to the use of salt and/or chemicals for the same solution. The objective of this study is to develop an electrically conductive structural concrete (compressive strength above $25 \mathrm{MPa}$ ) and analyze its thermoelectric and mechanical properties. The material was produced with the addition of steel fiber and graphite powder to generate a composite of low electrical resistivity, allowing the passage of sufficient electrical current to cause a significant increase in the surface temperature of the concrete.

\section{MATERIAL AND METHODS}

A concrete mixture 1:0.88:1.65:0.30:0.025 of cement, fine aggregate, coarse aggregate, water, and superplasticizer admixture was used as a reference. The cement consumption of this reference mixture was $622 \mathrm{~kg} . \mathrm{m}^{-3}$. Steel fibers and graphite powder were used in the electrically conductive concrete mixtures. Cement: the cement used was classified as type CPV-ARI [10], with Blaine fineness of $3035 \mathrm{~cm}^{2} \cdot \mathrm{g}^{-1}$ and a specific gravity of $2.81 \mathrm{~g} \mathrm{.cm}$. Fine aggregate: a natural fine pink sand as a fine aggregate with a fineness modulus of 1.2 and a specific gravity of $2.65 \mathrm{~g} . \mathrm{cm}^{-3}$ was used. Coarse aggregate: had a maximum characteristic size of $9.5 \mathrm{~mm}$, fineness modulus of 5.6 and a specific gravity of $2.66 \mathrm{~g} . \mathrm{cm}^{-3}$. Superplasticizer admixture: a polycarboxylatebased admixture (Adiment Premium, Vedacit), with a specific gravity of $1.09 \mathrm{~g} . \mathrm{cm}^{-3}$ was used. Graphite: we used additions of $5 \%, 10 \%, 15 \%$ and $20 \%$ in relation to cement mass of a natural crystalline graphite (Micrograf 99511UJ, Nacional de Grafite), with a carbon content greater than $99.5 \%$, specific gravity ranging from 0.055 to $0.116{\mathrm{~g} . \mathrm{cm}^{-3}}^{-3}$, and $\mathrm{D}_{50}$ smaller than $11 \mu \mathrm{m}$. Steel fiber: the fibers used were a carbon steel type AII (Tec-Machine) with an equivalent diameter of $0.60 \mathrm{~mm}, 30 \mathrm{~mm}$ in length and shape factor of 40 (steel anchored at the ends, originated from a cold-rolled sheet).

Mixing procedure: initially the coarse aggregate was prewetted with part of the water inside the concrete mixer and then the fine aggregate was added, mixing for $30 \mathrm{~s}$. After this time, the cement, the remaining water, and the admixture were added, keeping the concrete mixer running until it reached the desired consistency. Graphite powder and steel fiber were added to the end of the mixing.

Percolation transition zone test: the determination of the percolation transition zone was taken by mixing different volume fractions of steel fiber in the reference concrete. The steel fiber content varied from $0.5 \%$ to $9.0 \%$, with a step of $0.5 \%$, relative to the total volume of produced concrete. The plates used for the percolation transition zone test had dimensions of $25 \times 15 \times 5 \mathrm{~cm}$ and were made with two electrodes inserted on parallel faces (one on each side), as shown in Fig. 1. Two specimens for each fiber content were produced. The electrical resistivity of the material was determined by measuring with a multimeter (Minipa, 2070) the electric current passing through the concrete plate after applying a potential difference of $50 \mathrm{~V}$ by a Variac to the electrodes. With voltage $\mathrm{U}(\mathrm{V})$ and current i (A), it was possible to obtain the electrical resistance $\mathrm{R}(\Omega)$ :

$$
\mathrm{R}=\frac{\mathrm{U}}{\mathrm{i}}
$$

and then the electrical resistivity $\varrho(\Omega . m)$ was determined by:

$$
\rho=\frac{R \cdot A}{L}
$$

where A is the cross-sectional area of the element $\left(\mathrm{m}^{2}\right)$ and $\mathrm{L}$ is the length (m). From data of resistivity as a function of the content of conductive material, it was possible to determine the percolation transition zone and the optimal content of fibers to be used. The electrical conductivity $\left(\Omega^{-1}\right)$ is the inverse of the electrical resistivity, calculated according to:

$$
\text { Conductivity }=\frac{1}{\rho}
$$

Electrical conductivity and surface temperature tests: after determination of the optimal fiber content by the

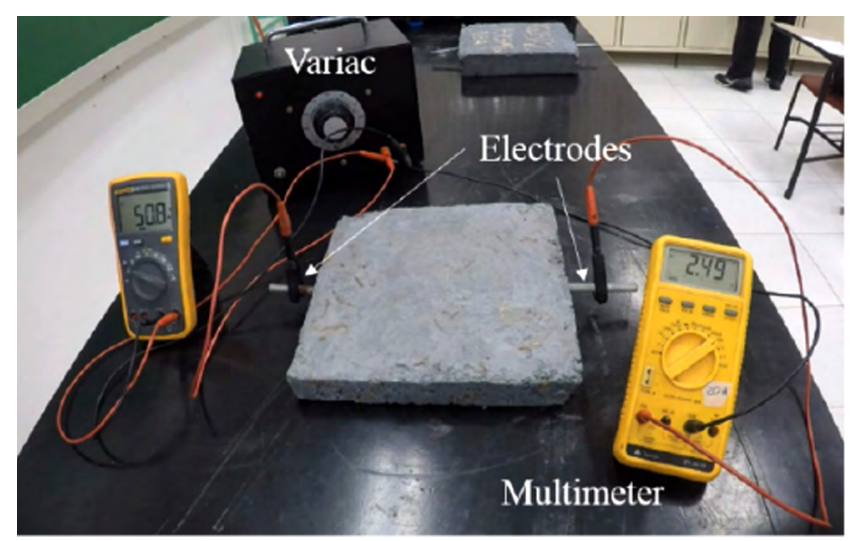

Figure 1: Image of electrical circuit used for percolation transition zone test.

[Figura 1: Imagem do circuito elétrico usado para o ensaio de limiar de percolação.] 
percolation transition zone test, steel fiber reinforced concrete plates with addition of graphite powder at the contents of $5 \%, 10 \%, 15 \%$ and $20 \%$ by mass of cement were produced with dimensions of $25 \times 25 \times 5 \mathrm{~cm}$ with two electrodes on parallel sides (one on each side) for electrical resistivity and surface temperature tests. One specimen for each admixture was produced. The passage of electric current through the concrete produced heat, which increased the temperature of the composite, promoting the heating of the plate as a whole, working as electrical resistance. For the measurement of the electric current, the same circuit used before to determine the percolation transition zone was used. Then a voltage of $50 \mathrm{~V}$ was applied and the temperature of the concrete surface was measured near the electrode positions with an infrared thermometer at $1 \mathrm{~min}$ intervals for $20 \mathrm{~min}$. Compressive strength test: three cylindrical test specimens having $10 \mathrm{~cm}$ diameter and $20 \mathrm{~cm}$ height of each mixture were prepared for compressive strength test, in accordance with the NBR 5738 standard [11] and then kept for 7 days in a humid chamber before testing.

\section{RESULTS AND DISCUSSION}

Percolation transition zone: Fig. 2 shows the results of the electric current measured during the application of a voltage of $50 \mathrm{~V}$ as a function of the steel fiber content incorporated into the concrete. The specimens were tested at the age of 7 days. It was possible to observe that between $0.5 \%$ to $4.0 \%$ of fiber content corresponded to the insulating

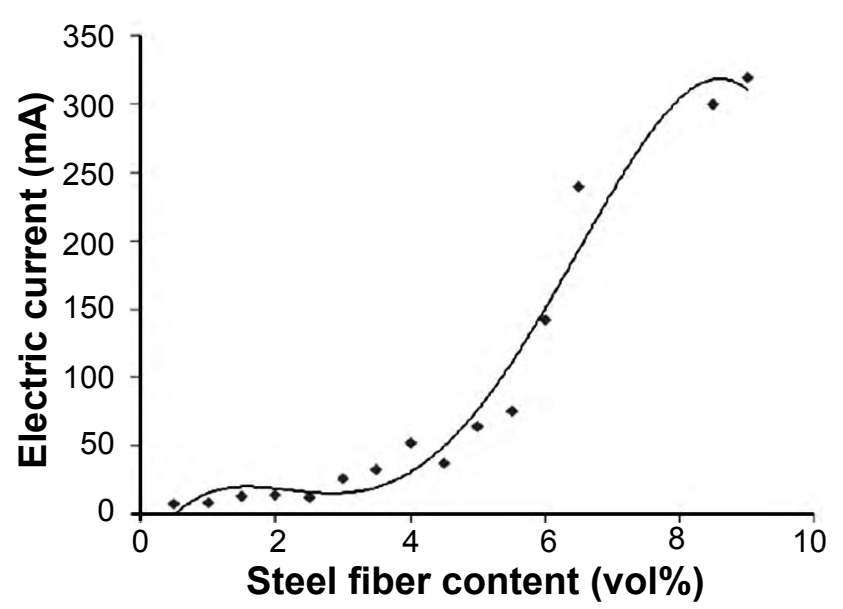

Figure 2: Results of percolation transition zone test. [Figura 2: Resultados do ensaio de limiar de percolação.] stage of the mixture; from $4.0 \%$ to $8.5 \%$ was the transition stage; $8.5 \%$ corresponded to the conductive stage and above that was the stage of the excess of fibers. For this mixture, $8.5 \%$ was then set as the optimal value for the steel fiber content. Above this value, the excess of fibers would not result in higher conductivity, as the shortest conductive path had already been reached. In addition, there would be further loss of workability of the mixture if more fibers were added.

Electrical conductivity: the $25 \times 25 \times 5 \mathrm{~cm}$ plates were tested for electrical conductivity. The voltage value was set at $50 \mathrm{~V}$ and the resultant electric current in each specimen was obtained. The resistivity values and finally the electrical conductivity values were calculated by Eqs. B and C, respectively. The results can be seen in Table I. It was concluded that the amount of graphite directly impacted the electrical conductivity of the mixture. The higher the content of graphite, the higher the electrical conductivity was, in almost linear proportion. The reference concrete presented practically no conductivity and was considered electrically insulating. Wu et al. [12] found electrical resistivity from 5.30 to $5.80 \Omega$.m for concretes with graphite contents of $2 \%$ to $8 \%$, values similar to those found for the concrete with $5 \%$ graphite of this study.

Surface temperature: Fig. 3 shows the surface temperature of the concrete plates measured during 20 min after applying a voltage of $50 \mathrm{~V}$. The final temperature at $20 \mathrm{~min}$ of test were: $25^{\circ} \mathrm{C}$ for the reference mixture; $37{ }^{\circ} \mathrm{C}$ for the mixture with $5 \%$ graphite $\left(12{ }^{\circ} \mathrm{C}\right.$ above the

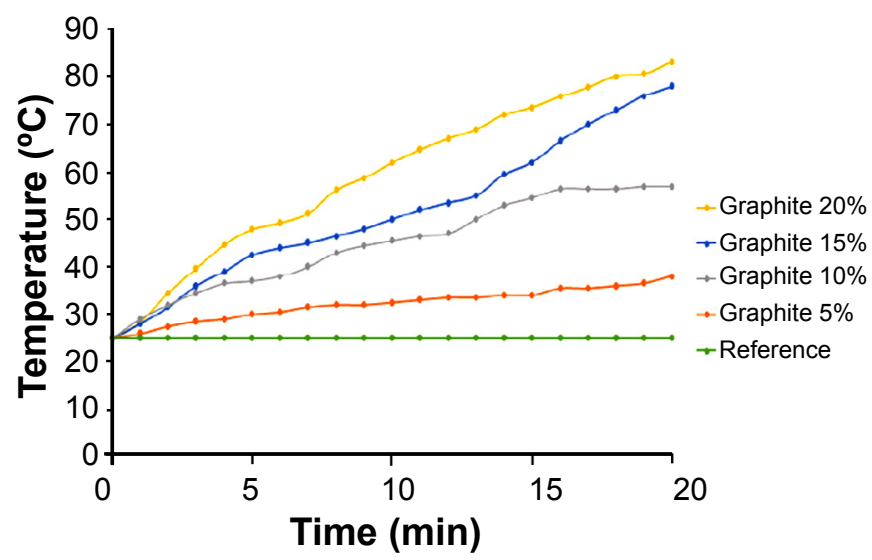

Figure 3: Temperature of the concrete surface as a function of time and graphite content with an applied voltage of $50 \mathrm{~V}$.

[Figura 3: Temperatura superficial do concreto em função do tempo e do teor de grafita com uma tensão aplicada de $50 \mathrm{~V}$.]

Table I - Electrical properties of the steel fiber reinforced concrete plates with the addition of graphite powder. [Tabela I - Propriedades elétricas das placas de concreto reforçado com fibras de aço com adição de pó de grafita.]

\begin{tabular}{cccccc}
\hline Property & Reference & Graphite $5 \%$ & Graphite $10 \%$ & Graphite $15 \%$ & Graphite $20 \%$ \\
\hline Current $(\mathrm{A})$ & $4.00 \times 10^{-3}$ & $5.20 \times 10^{-1}$ & $7.80 \times 10^{-1}$ & 1.06 & 1.56 \\
Resistance $(\Omega)$ & $1.25 \times 10^{4}$ & $9.62 \times 10$ & $6.41 \times 10$ & $4.72 \times 10$ & $3.21 \times 10$ \\
Resistivity $(\Omega . \mathrm{m})$ & $7.81 \times 10^{2}$ & 6.01 & 4.01 & 2.95 & 2.00 \\
Conductivity $\left(\Omega^{-1}\right)$ & $1.00 \times 10^{-3}$ & $1.66 \times 10^{-1}$ & $2.50 \times 10^{-1}$ & $3.39 \times 10^{-1}$ & $4.99 \times 10^{-1}$ \\
\hline
\end{tabular}




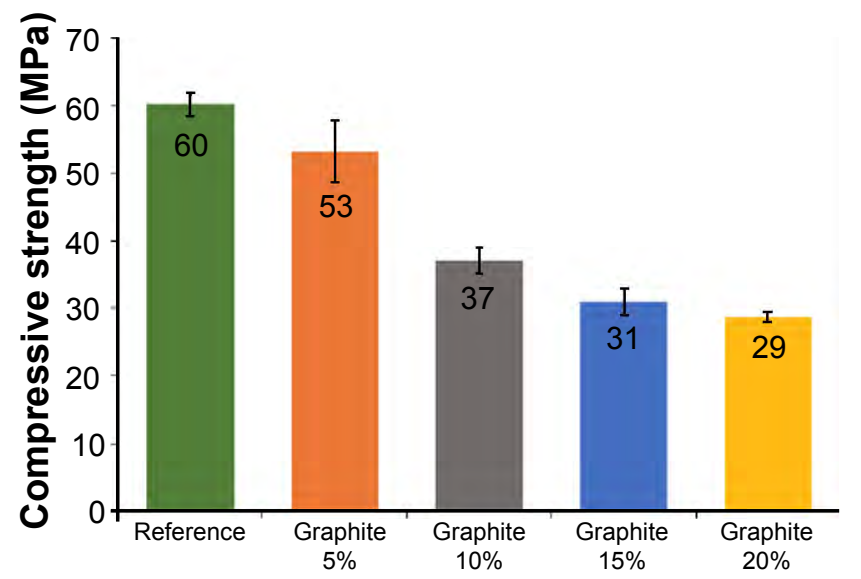

Figure 4: Compressive strength of the samples with different graphite content (7 days of age).

[Figura 4: Resistência à compressão das amostras com diferentes teores de grafita (7 dias de idade).]

reference mixture) $; 5{ }^{\circ} \mathrm{C}$ for the mixture with $10 \%$ graphite $\left(32{ }^{\circ} \mathrm{C}\right.$ above the reference mixture); $78{ }^{\circ} \mathrm{C}$ for the mixture with $15 \%$ graphite $\left(53{ }^{\circ} \mathrm{C}\right.$ above the reference mixture); and $83{ }^{\circ} \mathrm{C}$ for the mixture with $20 \%$ graphite $\left(58{ }^{\circ} \mathrm{C}\right.$ above the reference mixture). The average heating rates were 0.65 ${ }^{\circ} \mathrm{C} \cdot \mathrm{min}^{-1}$ for the mixture with $5 \%$ graphite, $1.6{ }^{\circ} \mathrm{C} \cdot \mathrm{min}^{-1}$ for the mixture with $10 \%$ graphite, $2.65^{\circ} \mathrm{C} \cdot \mathrm{min}^{-1}$ for the mixture with $15 \%$ graphite, and $2.95{ }^{\circ} \mathrm{C} \cdot \mathrm{min}^{-1}$ for the mixture with $20 \%$ graphite. As expected, the higher the graphite content, the higher the conductivity and the heating rate were and, consequently, the higher the final surface temperature of the concrete.

Compressive strength: Fig. 4 shows the results (mean and standard deviation) of axial compressive strength for the concretes produced with $8.5 \%$ of steel fiber and carbon contents varying from $0 \%$ (reference) to $20 \%$. The tests were carried out in accordance with the standard NBR 5739 standard [13]. The graphite content directly influenced the compressive strength of the concrete, with reductions of $12 \%, 38 \%, 49 \%$, and $52 \%$ for, respectively, $5 \%, 10 \%, 15 \%$, and $20 \%$ graphite powder contents in relation to cement. Because of its lamellar structure, the graphite facilitated the rupture of the contact planes, reducing the compression strength by half when mixture with $20 \%$ of graphite and the reference concrete were compared. The conductive concretes with steel fibers (20, 40, and $\left.60 \mathrm{~kg} \cdot \mathrm{m}^{-3}\right)$ and carbon black (1 $\mathrm{kg} \cdot \mathrm{m}^{-3}$ ) produced by Ding et al. [14] presented compressive strength varying from 35.4 to $39.9 \mathrm{MPa}$, close to the sample with $10 \%$ of graphite of this study. In [8], the compressive strength was reduced by $6 \%, 17 \%, 22 \%$, and $30 \%$ at 28 days of age for $1 \%, 3 \%, 5 \%$, and $7 \%$ volume replacement levels of graphite powder by volume of fine aggregate, respectively. By relating the respective values of strength and conductivity of each mixture, it was clear that the higher the graphite addition, the higher the electrical conductivity was, but also the lower was the compressive strength. Conductive concrete applications vary (both for temperature and structural requirements), so the ideal content of graphite added depends on the conditions of use.

\section{CONCLUSIONS}

The development of an electrically conductive concrete composed of different conductive materials was successfully accomplished. An optimum $8.5 \%$ steel fiber content was determined for the mixture by percolation transition zone test, which corresponded to the maximum content of steel fibers added to the mixture in order to produce the highest possible conductivity (percolation threshold). The electrical conductivity of the concrete increased with the increase of the incorporated graphite powder content, which also led to the increase of the surface temperature of the composite by up to $58^{\circ} \mathrm{C}$ above the reference mixture. The addition of graphite substantially impacted the mechanical strength of the concrete. The incorporation of $20 \%$ of graphite reduced the concrete strength from 60 to approximately 30 $\mathrm{MPa}$, which still characterize concrete with the potential to structural use.

\section{ACKNOWLEDGMENTS}

The authors would like to thank the companies Nacional de Grafite for the graphite powder donation, Tech-Machine for steel fibers donation, Vedacit for the superplasticizer donation, and Instituto Mauá de Tecnologia for the financial and laboratory supports.

\section{REFERENCES}

[1] C.Y. Tuan, "Implementation of conductive concrete for deicing (Roca Bridge)", Nebraska Dept. Transport. Res. (2008).

[2] A.A. Nepomuceno, in "Concreto: ensino, pesquisa e realizações", Ibracon, S. Paulo (2005) 793.

[3] S. Wen, D.D.L. Chung, Adv. Cem. Res. 15, 3 (2009) 119. [4] Á. García, E. Schlangen, M. van de Ven, Q. Liu, Constr. Build. Mater. 23, 10 (2009) 3175.

[5] F. Vossoughi, "Electrical resistivity of carbon fiber reinforced concrete", Un. California, Berkeley (2004).

[6] R.G. Arenhart, "Método de previsão de limiar de percolação e condutividade elétrica em compósitos poliméricos por simulação de Monte Carlo", M.Sc. Diss., Un. Fed. Santa Catarina (2012).

[7] H. Wang, J. Yang, H. Liao, X. Chen, Constr. Build. Mater. 122 (2016) 184.

[8] A.S. El-Dieb, M.A. El-Ghareeb, M.A.H. Abdel-Rahman, E.S.A. Nasr, J. Build. Eng. 15 (2018) 61.

[9] S. Wu, L. Mo, Z. Shui, Z. Chen, Carbon 43, 7 (2005) 1358.

[10] NBR 16697, “Cimento Portland: requisitos", Ass. Bras. Normas Téen., Rio Janeiro (2018).

[11] NBR 5738, "Concreto: procedimento para moldagem e cura de corpos de prova", Ass. Bras. Normas Técn., Rio Janeiro (2015).

[12] J. Wu, J. Liu, F. Yang, Constr. Build. Mater. 75 (2015) 
129.

[13] NBR 5739, "Concreto: ensaio de compressão de corpos de prova cilíndricos", Ass. Bras. Normas Técn., Rio Janeiro
(2018)

[14] Y. Ding, G. Liu, A. Hussain, F. Pacheco-Torgal, Y. Zhang, Constr. Build. Mater. 207 (2019) 630.

(Rec. 23/05/2019, Rev. 04/09/2019, Ac. 05/10/2019) 